
MILAN MIŠIĆ 1

\title{
Assessment of the integrity of welded pipes
}

\begin{abstract}
The subject of the paper is analysis of the integrity of welded pipes made of API J55 steel by high frequency contact welding (HF). Experimental research on the mechanical properties of the base material was conducted on pipes withdrawn from exploatation after 70000 hours at service. Defect influence of the surface crack on the integrity of pipes was tested using hydrostatic pressure of pipes with axial surface crack in the base material. Fracture behaviour was tested using modified compact specimen (CT), with the initial crack in the base material, welded joint and heat affected zone (HAZ). Critical value of the tensile strength factors $K_{l c}$ was determined based on the critical value $J$ of the integral $J_{l c}$.

Apart from the experimental research, based on the derived values of $K_{r}$ and $S_{r}$ and by applying fracture analysis diagram (FAD) an assessment of the integrity of welded pipes with axial surface crack on the outer surface area was conducted.
\end{abstract}

Keywords: seam casing pipes, axial surface crack, high frequency contact welding, fracture analysis diagram (FAD).

\section{INTRODUCTION}

Reliability of the pipeline system is important not only for the reasons of exploatation but also for the sake of perserving the environment. For the above reasons, research was conducted in order to assess fracture resistence of welded pipes and analysis of the integrity of pipeline system using fracture analysis diagram (FAD)was conducted. $\mathrm{Pi}$ pelines used in the process of exploatation can be made out of welded and seamless pipes respectively [1,2]. Specification of the pipeline system, according to the API 5CT standard, for the most part includes the properties of the pipeline system, such as are the dimensions of the pipes and joints, resistance of the pipeline system to internal and external pressure, as well as mechanical characteristics and chemical components.

Some of the developed standards and recommendations that were taken into consideration deal with the influence of large cracks on the integrity of pipes loaded with internal pressure and bending [3]. However, welded pipes can have axial surface cracks on the internal or external surface area, and can be subjected to diverse loading, including internal and external pressure, as well as axial loading (for example, due to the wight of the structure).

Methods for the assessment of the defect of pipes under pressure are important for maintaining safety and retaining stability of pipes in the plant [49]. The core part of the analysis of the integrity of

Author's address: ${ }^{1}$ High Technical School of Professional Studies, Zvečan, Serbia, ${ }^{2}$ Institute for Testing of Materials (IMS), Belgrade, Serbia, ${ }^{3}$ Faculty of Mechanical Engineering, Belgrade, Serbia, ${ }^{4}$ Faculty of Technology and Metallurgy, Belgrade, Serbia

Received for Publication: 18. 03. 2014.

Accepted for Publication: 25. 05. 2014. pipes is how to efficiently and precisely make an estimate of maximum allowed pressure and determine parameters of mechanical fracture, such as tensile strength factors $\left(\mathrm{K}_{\mathrm{Ic}}\right)$ and J-integral of defect pipes. As opposed to internal circular and axial semi-elliptic surface cracks $[4-15,17]$, a very limited number of studies is in the area which deals with the determination of $\mathrm{K}_{\mathrm{Ic}}$ and $\mathrm{J}$-integral for pipes with external axial semi-elliptic surface cracks [13]. So far, no detailed 3D finite element analysis (FEA) exist for a wide range of surface cracks on the external area of pipes. Conducted analysis mostly regard the application of 3D elasto-plastic finite element analysis for the determination of $\mathrm{J}$ integral for circular [16] and axial surface cracks on the external area of pipes[17].

In certain fracture analysis diagrams (FAD), limited loading of pipes with a crack is used to define $L r$ parameter which represents the value of plastic collapse [18]. In addition to this, when an assessment of the integrity of structures is conducted using R6 method [19], referential stress is defined by loading. In such cases loading is usually assessed for defects of high toughness(strength) steel $[20,21]$. Vast number of existing solutions for the pressure of pipes containing defects are developed analytically or empirically, based on the data derived from research [20]. These solutions were usually regarded as being too conservative, but the degree of conservatism can't be quantified. Recently, based on the finite element analysis, equations for determining pressure for cylinders with external axial semi-elliptic surface crack were developed [21]. However, suggested equations relate to a very limited number of defect dimensions as shown in [22], and in accordance with that, extended research with the aim of finding new solutions, is desirable. 
In this paper,analysis of the integrity of welded pipes with axial surface crack made of API-J55 was conducted. The pipe subjected to analysis was in the process of exploatation and was withdrawn during reparation procedure, after the period of service of approximately 70000 hours (8 years). This period is significantly shorter in comparison to projected work life of up to 30 years.

By CT testing using modified specimen, indirectly (using critical values $J$ of $J_{I c}$ integral) critical values of tensile strength factor $K_{/ c}$ were determined. Based on the critical value of tensile strength factor $K_{l c}$ for the base material, heat affected zone (HAZ) and seam metal, critical lengths of cracks were calculated.

For the assessment of the integrity of the pipeline system fracture analysis diagram(FAD) was applied. Based on the derived $K_{r} i S_{r}$ a point was Table 1 - Chemical components of API J55 steel [mas. \%] drawn into the fracture analysis diagram (FAD), and is located in the safe zone of the diagram. Having in mind the conservatism of FAD analysis in all its aspects, a conclusion can be made that welded pipes are safe not only from brittle fracture but plastic collapse as well.

\section{EXPERIMENTAL PROCEDURE}

Research shown in this paper was conducted with the aim of making an assessment of the integrity of pipes after a period of approximately 70 000 hours at service ( 8 years).

Properties of API J55 steel were determined on the samples collected from pipes made by HF welding. Diameter of analysed pipes was $\varnothing 139,7$ $\mathrm{mm}$ and nominal wall thickness $6,98 \mathrm{~mm}$. Chemical components of API-J55 steel are shown in table 1.

\begin{tabular}{|c|c|c|c|c|c|c|c|c|c|c|}
\hline C & $\mathrm{Si}$ & $\mathrm{Mn}$ & $P$ & $S$ & $\mathrm{Cr}$ & $\mathrm{Ni}$ & Mo & $\mathrm{V}$ & $\mathrm{Cu}$ & $\mathrm{Al}$ \\
\hline 0.2924 & 0.233 & 0.963 & 0.013 & 0.0216 & 0.0995 & 0.0579 & 0.0123 & 0.003 & 0.131 & 0.025 \\
\hline
\end{tabular}

$\left.{ }^{*} \mathrm{Ceq}=[\mathrm{C}+\mathrm{Mn} / 6+(\mathrm{Cr}+\mathrm{Mo}+\mathrm{V}) / 5+(\mathrm{Ni}+\mathrm{Cu}) / 15]=0.2924+0.963 / 6+(0.0995+0.0123+0.003) / 5++(0.0579+0.131) / 15\right]=0.49$

\subsection{Mechanical characteristics}

Positions of sample extraction for determination of mechanical characteristics of the base material and welded joint of cross welded pipes are defined by a standard [23].

Shape and dimensions of the samples used for the analysis of tensile properties are defined by a standard [24]. Measurement procedure for controlling defects is conducted using electromechanical testing device SCHENCK-TREBEL RM 100, the speed of introducing load tension is $5 \mathrm{~mm} / \mathrm{min}$.

Results derived by analysing tensile properties of the base material of the samples parallel to the direction of rolling, are shown in table 2 Test diagram is shown in figure 1 .

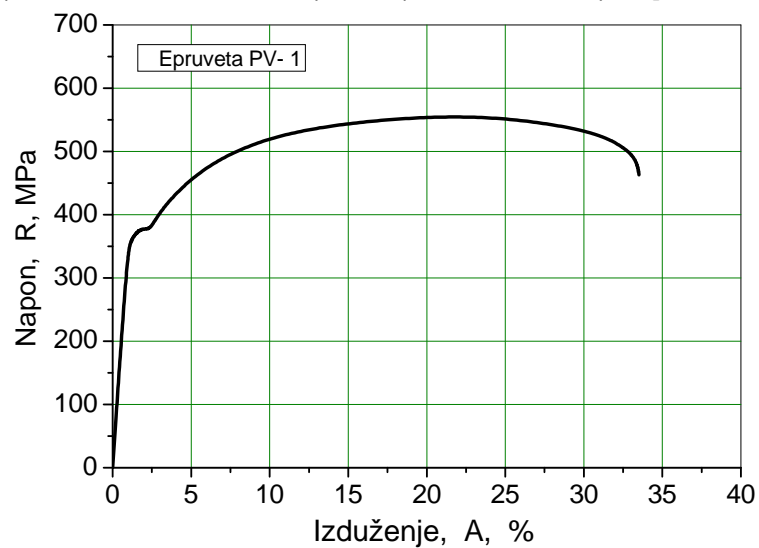

Figure 1 - Strain-stress diagram - elongation procentage, specimen $P V-1$, pipe withdrawn from exploatation, $20^{\circ} \mathrm{C}$

Table 2 - Tensile properties of the base material parallel to the direction of rolling

\begin{tabular}{|l|c|c|c|c|c|}
\hline \multicolumn{1}{|c|}{ Material } & Specimen & Temperature $\left[{ }^{\circ} \mathbf{C}\right]$ & $\mathbf{R}_{\mathrm{e}}[\mathrm{MPa}]$ & $\mathbf{R}_{\mathbf{m}}[\mathrm{MPa}]$ & $\mathbf{A}[\%]$ \\
\hline Exploited & $\mathrm{PV}$ & \multirow{2}{*}{20} & 380 & 562 & 33 \\
\cline { 1 - 4 } Standard API 5CT & & & $379-552$ & $>517$ & \\
\hline
\end{tabular}

\subsection{Fracture resistance}

Welded pipes under pressure can be extremly sensitive to cracks and their stable or unstable growth. Accordingly, it is of immense importance to determine reliable criteria for estimating the remaining life cycle of pipes under pressure with cracks in the base material and in welded joint. For the sake of better understanding of crack initiation and growth in welded pipes, exposed to high pressure and chemically agressive work environment, parameters used for controlling the behavior of materials at the tip of the crack and fracture resistance must be quantitatively expressed. Hence, critical value of the stress intensity factor $K_{I C}$, crack growth resistance curves (J- a), are experimentally investigated [25].

\subsubsection{Analysis of modified (CT) specimens}

Analysis using modified CT specimen, were conducted at room temperature using SCHENCKTREBEL RM 100 device. Thickness of modified CT specimen is $d=6,98 \mathrm{~mm}$ (equals the thickness of pipe walls) [25]. Indirectly (using a critical value $J$ of $J_{I c}$ integral) the critical value of stess intensity factor 
$K_{l c}$ is derived, and calculated using equation 1 and shown in table 3 :

$$
K_{I c}=\sqrt{\frac{J_{I c} \cdot E}{1-v^{2}}}
$$

By applying equation:

Table $3-K_{1 c}$ values- pipe withdrawn from exploitation

$$
K_{I c}=1,12 \cdot \sigma_{c} \cdot \sqrt{\pi \cdot a_{c}}
$$

And taking into consideration stress values, $\sigma=$ $\sigma_{c}$, (where $\sigma_{c}$ represents stress at fracture), approximative values of critical lengths of cracks

\begin{tabular}{|c|c|c|c|c|}
\hline Specimen mark & Temperature, $\left[{ }^{\circ} \mathrm{C}\right]$ & $\mathrm{J}_{\mathrm{lc},}[\mathrm{kN} / \mathrm{m}]$ & $\mathrm{K}_{\mathrm{Ic}},\left[\mathrm{MPa} \mathrm{m^{1/2 } ]}\right.$ & $\mathrm{a}_{\mathrm{c}},[\mathrm{mm}]$ \\
\hline BM-NR-E & \multirow{3}{*}{20} & 35.8 & 91.4 & 14.4 \\
\hline HAZ-NW-E & & 48.5 & 106.4 & 19.6 \\
\hline WM-NW-E & & 45.7 & 103.3 & 18.5 \\
\hline
\end{tabular}
are calculated $\left(a_{c}\right)$, za OM,HAZ i MŚ.
Based on the derived $K_{l c}$ values for the base material, heat affected zone and welded joint, base material is proven to be least resistent according to the parameters of initiation and crack drowth.

\section{ASSESSMENT OF THE INTEGRITY OF PIPES WITH AXIAL SURFACE CRACK}

Analysis were conducted on the canister under pressure, with axial surface crack in the base material, figure 2. Canister is made out of a piece of the welded pipe withdrawn from exploitation. On the external surface area ot the pipe, axial surface crack in the base material dimensions: $a=3,5 \mathrm{~mm}$ i $2 \mathrm{c}=200 \mathrm{~mm}$ is made by electroerosion.

The pipe prepared for hydrostatic pressure analysis is shown in figure. 3 .
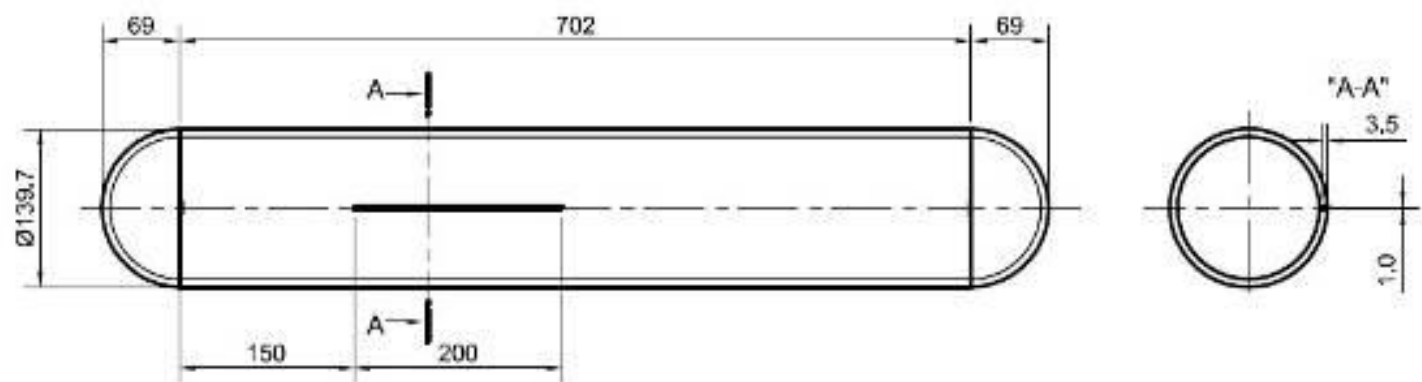

Figure 2 - Canister with axial surface crack in the external area

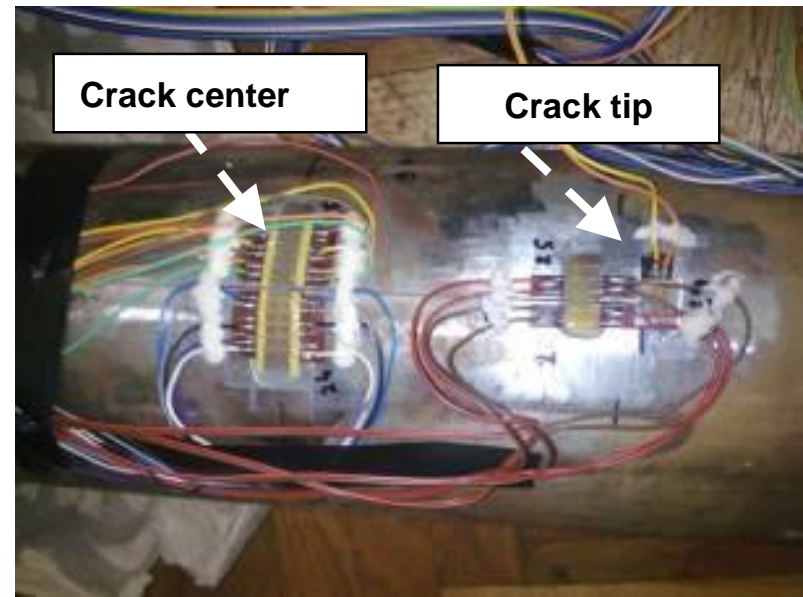

Figure 3 - Preview of the pipe prepared for analysis

Testing pressure is increased successively in steps from $1 \mathrm{MPa}$ to the pressure of $8 \mathrm{MPa}$, and then by $0,5 \mathrm{MPa}$ until reaching the pressure of 22 $\mathrm{MPa}$, whereat defects were registered using a linear strain gage LY 11-6/120, produced by HBM [26].
Diagrams od defect dependability on test pressure $p$ are shown in figures 4 do 7 .

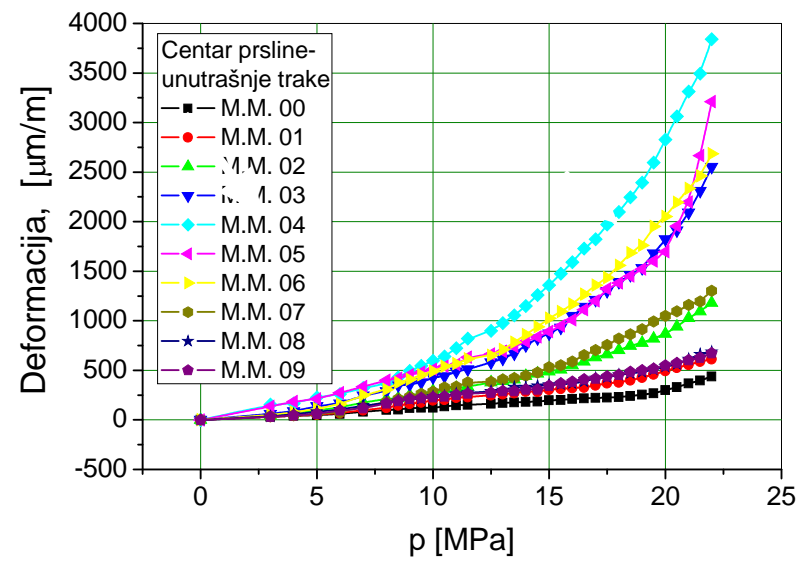

Figure 4 - Defects depending on pressure, inside strain gage - crack middle 


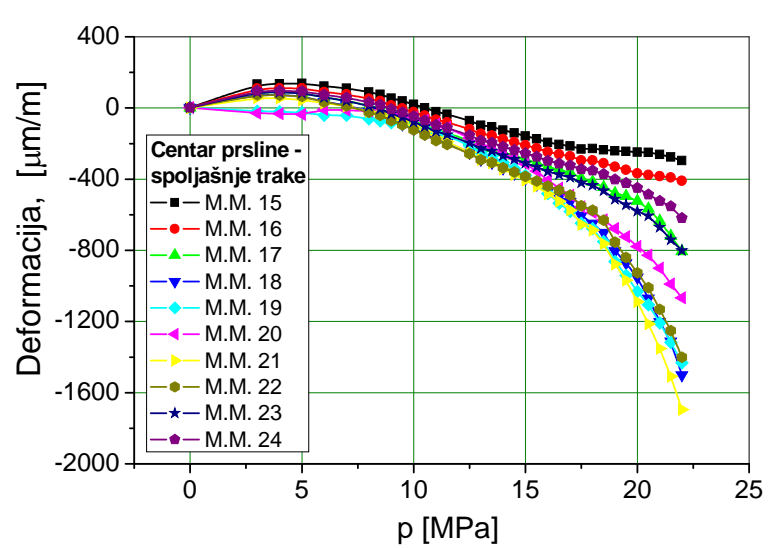

Figure 5 - Defects depending on pressure, outer strain gage - crack middle

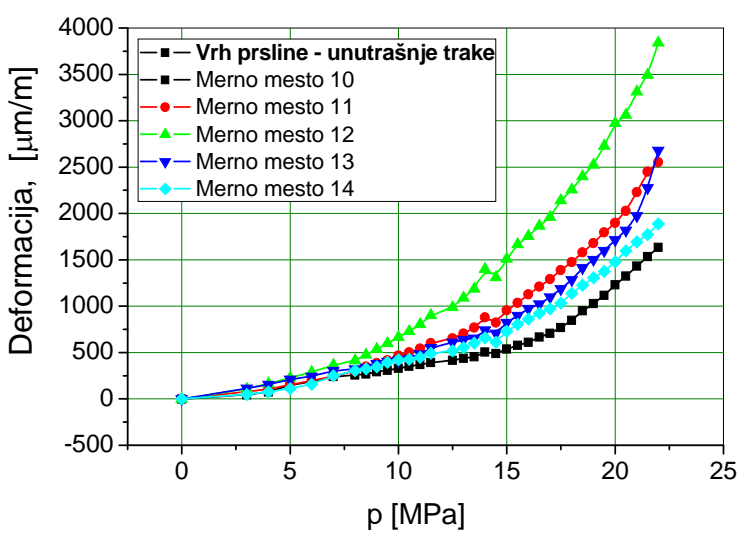

Figure 6 - Defects depending on pressure, inside strain gage - crack tip

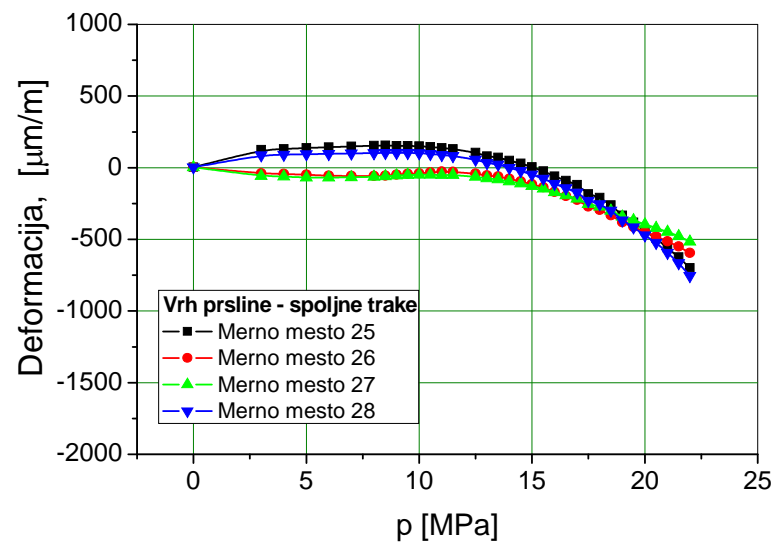

Figure 7 - Defects depending on pressure, outside strain gage - crack tip

\subsection{Fracture analysis diagram- $F A D$}

Structures made of tough materials are not susceptible to brittle fracture, but can fail by plastic collapse if they are overloaded. Plastic collapse mechanism is not encompassed by a CTOD (crack tip opening displacement) design curve, so its analysis requires a broader approach. Therefor, a concept with two fracture criteria was introduced in order to describe a mutual effect of a brittle fracture and a plastic collapse, realized using a Failure
Assessment Diagram - FAD) [27]. The base point of this diagram is a modified strip yield model for a temporary crack in an infinite plate, which connects effective stress intensity factor $K_{\text {eff }}$ to a non effective stress [28]:

$$
K_{\text {eff }}=\sigma_{Y} \sqrt{\pi a}\left[\frac{8}{\pi^{2}} \ln \sec \frac{\pi}{2} \frac{\sigma}{\sigma_{c}}\right]^{1 / 2}
$$

In real structures, flow stress $\sigma_{Y}$ should be substituted by collapse stress $\sigma_{C}$, which apart from materials also depends upon geometry of structures, including a crack. The next step in modifying FAD is expressing effective stress intensity factor in a non-dimensional form as $K_{\text {eff }} / K_{i}$ :

$$
\frac{K_{\text {eff }}}{K_{l}}=\frac{\sigma_{c}}{\sigma}\left[\frac{8}{\pi^{2}} \ln \sec \frac{\pi}{2} \frac{\sigma}{\sigma_{c}}\right]^{1 / 2}
$$

As a final step, non-dimensional variables, $S_{r}=\sigma / \sigma_{c}$ i $K_{r}=K / / K_{l c}$ are defined and they represent $\mathrm{X}$-axis and $\mathrm{Y}$-axis in a modified $\mathrm{FAD}$, figure 5 , and equation is transformed into:

$$
K_{r}=S_{r}\left[\frac{8}{\pi^{2}} \ln \sec \left(\frac{\pi}{2} S_{r}\right)\right]^{-1 / 2}
$$

If a material is completely tough, structures fail by plastic collapse at $S_{r}=1$, whereas structure fracture for completely brittle materials requires $K_{r}=1$. In all of the remaining cases there is an interaction between plastic collapse and brittle fracture, so $K_{r}$ i $S_{r}$ are less then 1 , and pairs of corresponding values form a border curve, shown in figure 8. Thereat $K_{\text {eff }}$ is taken to be equal to toughness of material fracture , $K_{l c}$, so $K_{r}$, is determined based on equation:

$$
K_{r}=\frac{K_{l}}{K_{l c}}
$$

For calculating $S_{r}$ only primary stresses are taken into consideration, as secondary stresses do not influence structure collapse.

Using a handbook, for geometry shown in figure $2 K_{r}$ factor, is expressed using a following equation:

$$
\begin{aligned}
& K_{I}=\sqrt{\frac{\pi a}{Q}} \frac{p R_{i}^{2}}{R_{o}^{2}-R_{i}^{2}} \mathrm{~g} \\
& \mathrm{~g}\left[2 G_{0}+2\left(\frac{a}{R_{i}}\right) G_{1}+3\left(\frac{a}{R_{i}}\right)^{2} G_{2}+4\left(\frac{a}{R_{i}}\right)^{3} G_{3}\right](6
\end{aligned}
$$

a constant $Q$ is calculated based on:

$$
Q=1+1,464\left(\frac{a}{c}\right)^{1,65}
$$

where $G_{j}$ values depend upon $a / c$, a/t and $t / R_{i}$ and are shown in a reference list [13]. Relevant $G_{j}$ 
values for the purpose of this research are derived by interpolation and extrapolation are:

$$
\begin{array}{ll}
G_{0}=1,584 & G_{1}=0,839 \\
G_{2}=0,600 & G_{3}=0,480
\end{array}
$$

At initial depth $a=3,5 \mathrm{~mm}$ and crack length $2 \mathrm{C}=200 \mathrm{~mm}$ the derived equation is

$$
\begin{aligned}
& Q=1,0058 \text { i } K_{I}=32,067[\mathrm{MPa} \sqrt{m}] \\
& K_{r}=\frac{K_{I}}{K_{I c}}=\frac{32,067}{91,4}=0,35
\end{aligned}
$$

Stress at net intersection equals $\sigma_{n}=2 p R / t$, whereat factor 2 was taken due to weakened intersection by a crack of $3,5 \mathrm{~mm}$ length and $6,98 \mathrm{~mm}$ thickness $(50 \%)$, to get

$$
S_{r}=\frac{2\left(\frac{2 p R}{t}\right)}{\left(R_{e H}+R_{m}\right)}=\frac{2\left(\frac{2 \cdot 22 \cdot 69,85}{6,98}\right)}{(380+562)}=0,93
$$

Based on the derived values of $K_{r}$ i $S_{r}$ a point with coordinates $(0,93 ; 0,35)$ located in the unaffected zone of a diagram was drawn into a fracture analysis diagram FAD, figure 8.

Table $4-K_{r} i S_{r}$ parameter values depending on a pressure change

\begin{tabular}{|c|c|c|c|c|}
\hline $\mathbf{A}[\mathbf{m m}]$ & $\mathbf{t}[\mathbf{m m}]$ & $\mathbf{p}[\mathbf{M P a}]$ & $\mathbf{K}_{\mathbf{r}}$ & $\mathbf{S}_{\mathbf{r}}$ \\
\hline 3,5 & 6,98 & 22 & 0,35085 & 0,93485 \\
\hline 3,5 & 6,98 & 20 & 0,31895 & 0,84987 \\
\hline 3,5 & 6,98 & 18 & 0,28706 & 0,76488 \\
\hline 3,5 & 6,98 & 16 & 0,25516 & 0,67989 \\
\hline 3,5 & 6,98 & 14 & 0,22327 & 0,59491 \\
\hline 3,5 & 6,98 & 12 & 0,19137 & 0,50992 \\
\hline 3,5 & 6,98 & 10 & 0,15948 & 0,42493 \\
\hline 3,5 & 6,98 & 8 & 0,12758 & 0,33995 \\
\hline
\end{tabular}

Table 4 shows $K_{r}$ and $S_{r}$ parameter values depending on the pressure change. Derived $K_{r}$ and $\mathrm{S}_{r}$ values are drawn into a fracture analysis diagram(FAD), figure 9 .

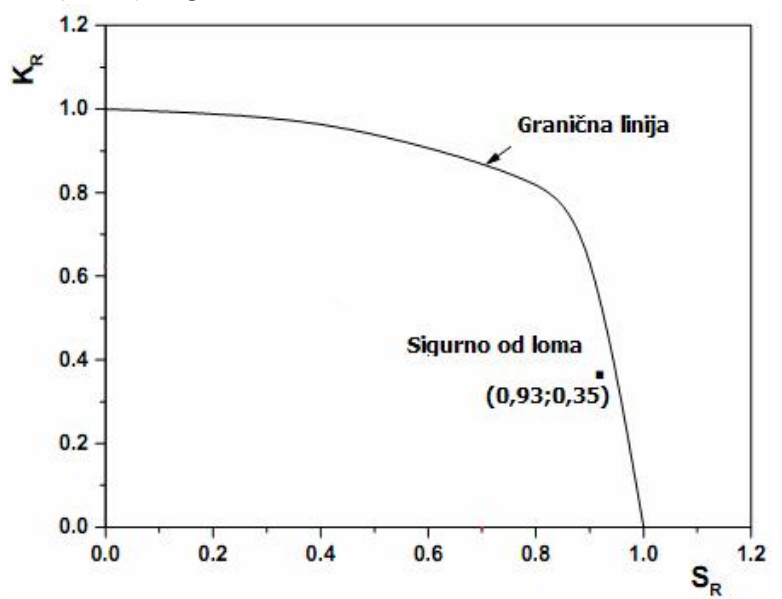

Figure 8 - Fracture analysis diagram (FAD) for a pipe with axial surface crack on the outer surface

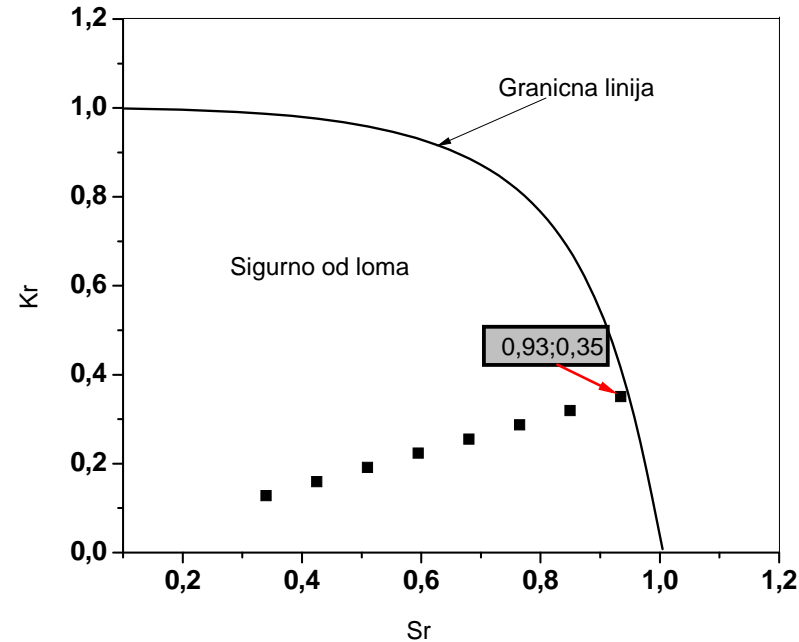

Figure 9 - Fracture analysis diagram (FAD) for a pipe with axial surface crack on the outer surface area at different pressures

\section{CONCLUSION}

In this paper, assessment of the integrity of welded pipes with axial surface crack on the outer surface of pipes made of API-J55 steel is conducted using fracture mechanics.

Based on the critical values of stress intensity factor $K_{l c}$ of the base material, heat affected zone HAZ and weld metal critical lengths of cracks are calculated. Based on the derived results, base material is proven to be least resistant according to crack initiation and growth.

Having in mind conservativeness of FAD analysis in all its aspects, a conclusion can be made that welded pipes are safe not only from brittle fracture, but also from plastic collapse. It is important to note that FAD enables a simple assessment of the integrity, which can ascertain with reliability weather a welded pipe is safe from fracture, under the condition that geometry and loading are represented in a conservative way. On the other hand, if integrity can not be proven, this does not mean that a welded pipe is useless, but that additional, more complex analysis are required.

\section{Acknowledgments}

We gratefully acknowledge the financial support from the Serbian Ministry of Science under the project EVB: TR 35002.

\section{REFERENCES}

[1] Arsić M. (2002) Choice of steel for welded tubes production; Welding Weld Struct, 47, 33-37, Serbian.

[2] Šarkoćević Ž, Arsić M, Rakin M, Sedmak A. (2008) Fabrication of welded tubes by high strength steel and quality indicators; Struct Integr Life, 8, 81-98.

[3] Sanjeev S, Ramachandra Murthy DS (2007) On the accuracy of ductile fracture assessment of throughwall cracked pipes; Engineering Structures, 29, 789-801. 
[4] Kumar $V$ and German MD. Elastic-plastic fracture analysis of through-wall and surface flaws in cylinders. EPRI Report, NP-5596, 1988.

[5] Zahoor A. Ductile fracture handbook. Novetech Corp, 1991.

[6] R6: Assessment of the integrity of structures containing defects, revision 4. British Energy Generation Ltd., 2001.

[7] ASME, Rule for in-service inspection of nuclear power plant components - ASME Boiler and Pressure Vessel Code, Section XI (1996).

[8] API, API RP579 - Recommended Practice for Fitness-For-Service. American Petroleum Institute, 2000.

[9] Miller AG. (1988) Review of limit loads of structures containing defects; International Journal of Pressure Vessels and Piping, 32, 191-327.

[10] Jones MR. \& Eshelby JM. Limit solutions for circumferentially cracked cylinders under internal pressure and combined tension and bending. Nuclear Electric Report TD/SID/REP/0032, 1990.

[11] Delfin P. Limit load solutions for cylinders with circumferential cracks subject to tension and bending SAQ/FoU Report 96/95, SAQ Kontroll AB, Stockholm, Sweden, 1998.

[12] Kim YJ, Shim DJ, Huh NS and Kim YJ (2002) Plastic limit pressure for cracked cylinders using finite element limit analyses; International Journal of Pressure Vessels and Piping, 79, 321-330.

[13] Raju IS and Newman JC. (1982) Stress-intensity factors for internal and external surface cracks in cylindrical vessels; Journal of Pressure Vessel Technology, 104, 293-298.

[14] Bergman M. (1995) Stress intensity factors for circumferential surface cracks in pipes; Fatigue and Fracture of Engineering Materials and Structures, 18, 1155-1172.

[15] Fett T. and Munz D. Stress Intensity Factors and Weight Functions. Computational Mechanics Publications, 1997

[16] Kim YJ, Kim JS, Kim YJ. (2002) Non-linear fracture mechanics analyses of part circumferential surface cracked pipes; Internal Journal of Fracture, 116 347-375.
[17] Kim YJ, Kim JS, Park YJ and Kim YJ. (2004) Elastic-Plastic Fracture Mechanics Method for Finite Internal Axial Surface Cracks in Cylinders; Engineering Fracture Mechanics, 71, 925-944.

[18] Zerbst U, Hamann R and Wohlschlegel A. (2000) Application of the European flaw assessment procedure SINTAP to pipes; International Journal of Pressure Vessels and Piping, 77,697-702.

[19] Ainsworth RA. (1984) The assessment of defects in structures of strain hardening material. Engineering Fracture Mechanics, 19,633-642.

[20] Miller AG. (1988) Review of limit loads of structures containing defects; International Journal of Pressure Vessels and Piping, 32,191-327.

[21] Kim YJ, Shim DJ, Nikbin K, Kim YJ, Hwang SS. and Kim JS (2003) Finite element based plastic limit loads for cylinders with part-through surface cracks under combined loading; International Journal of Pressure Vessels and Piping, 80,527-540.

[22] Tonković Z, Skozrit I. Elastoplastic Analysis of External Axial Surface Cracks in Tubes. Proceedings of the ICCES'04, International Conference on Computational \& Experimental Engineering and Sciences, Tadeu, A., Atluri, S. N. (eds.), Madeira, Portugal, 26-29 July 2004.

[23] API Spec 5CT, Specification for casing and tubing, American Petroleum Institute, 2002.

[24] ASTM A370-94, Standard test methods and definitions for mechanical testing of steel products, 1994.

[25] Šarkoćević Ž, Arsić M, Medjo B, Kozak D, Rakin M, Burzić Z, Sedmak A. (2009) Damage level estimate of API J55 steel for welded seam casing pipes; J Theory Appl Mech Eng, 51, 303-11.

[26] Šarkočević Ž „Otpornost prema oštećenju i lomu zaštitnih zavarenih cevi u naftnim bušotinama", Doktorska disertacija, Univerzitet u Beogradu, 2010

[27] Harrison RP et al. (1975) Assessment of the Integrity of Structures Containing Cracks; International Journal of Pressure Vessels and Piping, 3,77-137.

[28] Dugdale DS. (1960) Yielding in Thin Sheets Containing Slits, J. Mechanics and Physics of Solids, 8,100-104

\section{IZVOD}

\section{PROCENA INTEGRITETA ZAVARENIH CEVI}

Predmet rada je analiza integriteta zavarenih cevi izrađenih od čelika API J55 visokofrekventnim kontaktnim zavarivanjem (VF). Eksperimentalna ispitivanja mehaničkih osobina osnovnog materijala su izvršena na cevima povučenim iz ekspolatacije posle 70000 sati rada. Uticaj oštećenja tipa površinske prsline na integritet cevi ispitan je hidrostatičkim pritiskom cevi sa aksijalnom površinskom prslinom u osnovnom materijalu. Ponašanje pri lomu je ispitivano korištenjem modifikovanih kompaktnih epruveta za zatezanje (CT), s početnom prslinom u osnovnom materijalu, zavarenom spoju i zoni uticaja toplote (ZUT). Kritična vrednost faktora intenziteta napona $K_{l c}$ određena je na osnovu kritične vrednosti $J$ integrala $J_{l c}$. Osim eksperimentalnog istraživanja, na osnovu dobijenih vrednosti za $K_{r}$ i $S_{r}$ primenom dijagrama analize loma (FAD) izvršena je procena integriteta zavarenih cevi sa aksijalnom površinskom prslinom na spoljašnjoj površini.

Keywords: aksijalna površinska prslina, visokofrekventno kontaktno zavarivanje, dijagram analize loma (FAD).

Originalni naučni rad

Rad primljen 18. 03. 2014.

Rad prihvaćen 25. 05. 2014. 